\title{
ANALYSIS THE IMPACT OF GOVERNMENT PROLIFERANTION ON EDUCATIONAL AND ECONOMIC \\ Dalila Husna $^{1}$ \\ Rumayya*2
}

1,2Department of Economics, Universitas Airlangga, Indonesia

\section{ABSTRACT}

The government proliferantion in Indonesia become a consequence of the existence of a policy of fiscal desentalisasi. The existence of the government proliferantion is expected to shorten the span of control so that the goal of improving the well-being of society and the public service can be achieved. This study goals to analyze the impact of the government proliferantion on the regional educational and economic outcomes against on 491 Kabupaten/Kota in Indonesia. This research uses the Difference in Difference as a tool of analysis. Data obtained from the Indodapoer-World Bank year 2001 until 2014. The impact of the presence of the government proliferantion against outcomes education is lowering the level of literacy through a decrease in the number of buildings on the SD output though it is insignificant and its impact on economic outcomes effect increasing income per capita community that in proxy through household spending per capita and GDP per capita, increasing the number of workers, and lower levels of poverty through increased output in the electricity, road access to the village dirt road, and the village gravel road. The impact in General of the expansion area is a local Government has succeeded in transferring funds to the poor but not with a business climate that is shown by the results of the constant price GDP as a whole which indicates significant results negative.

Keywords: Government Proliferantion, Difference in Difference, Educational, Economic.

JEL : R1, HOO, I21, 125

\section{ABSTRAK}

Pemekaran daerah di Indonesia menjadi konsekuensi dari adanya kebijakan desentalisasi fiskal. Adanya pemekaran daerah diharapkan dapat memperpendek rentang kendali sehingga tujuan meningkatkan kesejahteraan masyarakat dan pelayanan publik dapat tercapai. Studi ini bertujuan untuk menganalisis dampak dari adanya pemekaran daerah terhadap pendidikan dan ekonomi di 491 Kabupaten/Kota di Indonesia. Penelitian ini menggunakan Difference in Difference sebagai alat analisis. Data diperoleh dari Indodapoer-World Bank tahun 2001 hingga 2014. Dampak adanya pemekaran daerah terhadap pendidikan adalah menurunkan tingkat literasi melalui penurunan output pada jumlah bangunan SD meskipun secara tidak signifikan dan dampaknya terhadap ekonomi berpengaruh meningkatkan pendapatan per kapita masyarakat yang di proksi melalui pengeluaran rumah tangga per kapita dan GDP per kapita, meningkatkan jumlah pekerja, dan menurunkan tingkat kemiskinan melalui peningkatan output pada akses listrik, jalan desa yang bertanah, dan jalan desa yang diperkeras. Dampak secara umum dari adanya pemekaran daerah adalah pemerintah daerah telah berhasil mentransfer dana kepada masyarakat miskin namun tidak dengan iklim usaha yang ditunjukkan oleh hasil GDP harga konstan secara keseluruhan yang menunjukkan hasil signifikan negatif.

Kata Kunci: Pemekaran Daerah, Difference in Difference, Pendidikan, Ekonomi.

\section{RIWAYAT ARTIKEL}

Tanggal Masuk:

3 Agustus 2021

Tanggal Revisi:

23 Oktober 2021

Tanggal Diterima:

23 November 2021

Tersedia Online:

29 November 2021

*Korespondensi:

Rumayya

E-mail:

rumayya@feb.unair.ac.id

JEL : R1, HOO, I21, 125

JIET (Jurnal IImu Ekonomi Terapan) p-ISSN: 2541-1470; e-ISSN: 2528-1879 DOI: 10.20473/jiet.v6i.31141

Open access under a Creative Commons Attribution-ShareAlike 4.0 International

(CC BY-SA) 


\section{Pendahuluan}

Berakhirnya rezim orde baru pada tahun 1998 menjadi babak baru perubahan pada struktur pemerintahan di Indonesia secara keseluruhan yang semula sentralistik menjadi desentralistik yang ditandai dengan adanya pergeseran kekuasaan dari pemerintah pusat ke pemerintah daerah. Konsekuensi dari adanya kebijakan desentralisasi adalah munculnya pemekaran daerah, yang pada awalnya dilandasi oleh UU Nomor 22 Tahun 1999. Secara teknis pedoman pelaksanaan UU Nomor 22 Tahun 1999 diatur dalam PP Nomor 129 Tahun 2000 tentang Persyaratan pembentukan dan kriteria pemekaran, penghapusan, dan penggabungan daerah yang menyatakan bahwa pemekaran daerah harus memenuhi persyaratan seperti kemampuan ekonomi, potensi daerah, sosial budaya, sosial politik, jumlah penduduk, luas daerah, dan pertimbangan lainnya yang memungkinkan terlaksananya otonomi daerah. Proses pemekaran daerah pada peraturan tersebut bersifat bottom up. Dengan terbentuknya daerah baru diharapkan dapat menggali setiap potensi kebudayaan dan sumber daya alam dari setiap daerah provinsi dan kabupaten/kota masing-masing. Adanya pemekaran daerah telah membentuk Daerah Otonom Baru (DOB).

Perkembangan Daerah Otonom Baru (DOB) semenjak tahun 1999 hingga 2014 terus mengalami peningkatan, yaitu ada 222 Daerah Otonom Baru (DOB). Selama masa orde baru, jumlah provinsi dan kab/kota hanya ada 319 daerah selanjutnya setelah tahun 1999 hingga 2014 meningkat terus hingga 2014 jumlah provinsi dan kabupaten/kota ada 542 daerah. Adanya perkembangan jumlah Daerah Otonom Baru (DOB) dapat ditunjukkan pada Gambar 1 yang mana pemekaran kabupaten/kota lebih sering terjadi dibandingkan pemekaran provinsi yang hanya terjadi 5 kali yaitu pada tahun 1999, 2000, 2002, 2004, dan 2012. Sedangkan untuk pemekaran kabupaten/kota terjadi hampir setiap tahun namun ada masa-masa pemekaran daerah tersebut konstan yaitu pada tahun 2000, 2004 hingga 2006, 2010 hingga 2011, serta 2014 hingga 2017 hal ini dikarena pada tahun-tahun tersebut telah terjadi moratorium pemekaran daerah.

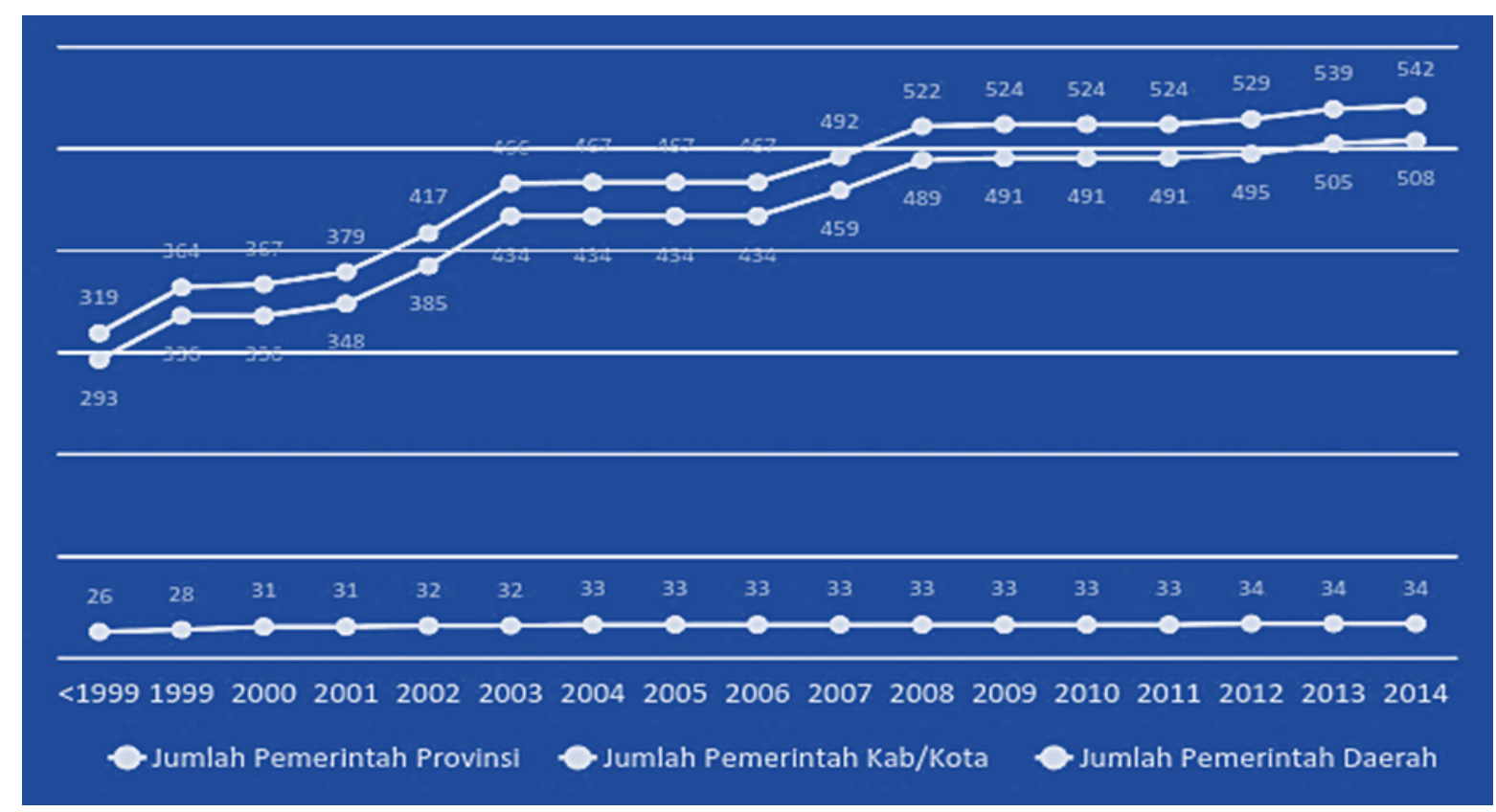

Sumber : Kementerian Dalam Negeri (2018) dan Jaweng (2014), Diolah.

Gambar 1: Perkembangan Daerah Otonom Baru (DOB) Provinsi dan Kabupaten/Kota di Indonesia, $1999-2014$ 
Terdapat beberapa penelitian sebelumnya mengenai dampak pemekaran daerah dengan menggunakan Difference in Difference (DiD) sebagai alat analisisnya. Metode Difference in Difference (DiD) biasanya digunakan untuk menganalisis dampak dari suatu kebijakan yang mensyaratkan berada dalam dua periode waktu, yaitu sebelum dan sesudah di kelompok yang mengalami treatment dan kelompok yang tidak mengalami treatment. Penelitian tersebut diantaranya oleh Lewis (2017); Qibthiyyah (2010). Penelitian yang dilakukan oleh Lewis (2017) menganalisis dampak pemekaran daerah terhadap aspek pendidikan dan infrastruktur. Hasilnya menemukan bahwa adanya pemekaran daerah lebih berdampak ke aspek infrastruktur dibandingkan aspek pendidikan, dimana kondisi infrastruktur daerah anak lebih rendah dibandingkan dengan daerah induk.

Penelitian dari Qibthiyyah (2010) menganalisis dampak dari pemekaran daerah terhadap aspek pendidikan dan kesehatan. Di aspek pendidikan, adanya penurunan tingkat drop out tidak membuat peningkatan pada nilai rata-rata ujian sekolah. Di aspek kesehatan, menunjukkan adanya peningkatan jumlah kematian bayi. Hal ini menunjukkan bahwa dampak pemekaran daerah terhadap pendidikan dan kesehatan tidak berdampak semakin membaik. Pemerintah daerah mencurahkan lebih dari setengah anggaran belanja mereka untuk pemberian layanan di sektor pendidikan dan infrastruktur (World Bank, 2012). Ketersediaan pelayanan infrastruktur memainkan peranan penting dalam pembangunan daerah. Infrastruktur tidak saja diperlukan untuk meningkatkan lalu lintas informasi serta kegiatannya tetapi juga untuk mendukung kegiatan pemerintah yang bersifat administrative, kegiatan pelayanan publik, serta mendukung roda kegiatan ekonomi (Bappenas, 2008).

Berdasarkan latar belakang yang telah dijabarkan diatas, penulis dalam penelitian ini tertarik untuk menganalisis mengenai dampak dari pemekaran daerah terhadap pendidikan dan ekonomi karena belum ada studi yang membahas mengenai outcome berkelanjutan dari penganggaran terhadap pendidikan dan infrastruktur. Variabel outcome pendidikan yang diteliti adalah tingkat literasi dan variabel outcome ekonomi yang diteliti adalah terkait pendapatan per kapita, tenaga kerja, dan tingkat kemiskinan. Hal lainnya yang membedakan penelitian ini dengan penelitian lainnya adalah mengambil tahun observasi yang lebih panjang, yaitu tahun 2001 hingga 2014 karena seperti yang diketahui bahwa untuk menganalisis dampak membutuhkan waktu yang lebih panjang untuk bisa melihat dampaknya secara jauh. Atas dasar hal inilah maka penelitian ini akan menganalisis sampai sejauh mana pemekaran daerah memberikan andil terhadap kondisi pendidikan dan ekonomi di Indonesia.

\section{Telaah Literatur}

Pemekaran daerah di Indonesia adalah pembentukan wilayah administratif baru di tingkat provinsi maupun kota dan kabupaten dari induknya (Kemendagri, 2014). Landasan hukum terbaru untuk pemekaran daerah di Indonesia adalah UU No 23 Tahun 2014 tentang Pemerintahan Daerah. UUD 1945 tidak mengatur perihal pembentukan daerah atau pemekaran suatu wilayah secara khusus, namun disebutkan dalam Pasal 18B ayat (1): "Negara mengakui dan menghormati satuan-satuan pemerintahan daerah yang bersifat khusus atau bersifat istimewa yang diatur dengan undang-undang." Selanjutnya, pada ayat (2) pasal yang sama tercantum kalimat sebagai berikut. "Negara mengakui dan menghormati kesatuan-kesatuan". Menurut Peraturan Pemerintah No 78 Tahun 2007, pemekaran daerah/wilayah adalah pemecahan suatu pemerintah baik propinsi, Kabupaten/Kota, Kecamatan, Desa / Kelurahan menjadi dua daerah atau lebih. Adapun syarat-syarat pembentukan daerah yang tertuang dalam Pasal 3 Undang-Undang Nomor 22 Tahun 1999 adalah kemampuan daerah, potensi daerah, sosial budaya, sosial politik, jumlah penduduk, luas daerah, dan pertimbangan lain yang memungkinkan terselenggaranya otonomi daerah seperti keamanan dan ketertiban, keterse- 
diaan sarana dan prasarana pemerintahan, rentang kendali, serta peraturan minimal daerah terbentuknya, misalnya untuk pemerintah provinsi minimal harus terdiri dari tiga kabupaten dan/atau kota serta pemerintah kabupaten/kota minimal terbentuk tiga kecamatan.

Pemekaran daerah merupakan konsekuensi dari adanya kebijakan desentralisasi, sehingga menjadi sangat mungkin dalam menganalisis dampak pemekaran wilayah dijelaskan dalam kerangka teori fiscal federalism. Teori tersebut mempunyai dua pandangan, yaitu Teori Tradisional atau disebut Teori Generasi Pertama (First Generation Theories) dan Teori Perspektif Baru atau Teori Generasi Kedua (Second Generation Theories). Zaenuddin (2015) menjelaskan dalam Teori Generasi Pertama ada dua pendapat yang menyebutkan adanya keuntungan dari adanya alokatif desentralisasi. Dalam konteks pengambilan keputusan, Knowledge in society sangat menguntungkan karena adanya pemerintah daerah yang lebih dekat dengan masyarakat akan mempermudah proses pengambilan keputusan yang terdesentralisasi sehingga keputusan yang diambilpun juga diharapkan langsung berdampak terhadap masyarakat daerah (Hayek, 1945). Selanjutnya dalam konteks keuangan publik, allocative efficiency akan membuat pemerintah daerah lebih baik dalam pengambilan keputusan terkait penyediaan barang dan jasa publik dibandingkan dengan penyediaan hal tersebut oleh pemerintah pusat karena pemerintah daerah mempunyai informasi yang lebih baik dibandingkan dengan pemerintah pusat tentang kondisi daerah masing-masing.

Pandangan Teori Generasi Kedua merupakan perspektif baru dari Teori Generasi Pertama yang dibangun oleh Musgrave (1959); Oates (1972) yang menekankan pentingnya revenue dan expenditure assignment antar level pemerintahan atau dengan kata lain teori ini mencoba menjelaskan desentralisasi fiskal berpengaruh terhadap perilaku pemerintah daerah yang mana ada pembatasan atas campur tangan pemerintah pusat terhadap pemerintah daerah karena pemerintah daerah memiliki kewenangan membuat peraturan mengenai ekonomi lokal. Teori ini menyelaraskan antara kepentingan pemerintah daerah dengan kemakmuran ekonomi, interaksi horizontal antar pemerintah daerah, dan interaksi vertical antar level pemerintahan melalui dua mekanisme.

Dua Mekanisme yang dimaksud adalah Pertama, harus adanya penyelarasan antara peraturan pemerintah daerah dan penyediaan barang dan jasa publik terhadap pasar dan masyarakat. Kedua, Upaya peningkatan kemakmuran ekonomi daerah sebagai insentif dari keterkaitan erat antara penerimaan daerah dengan pengeluaran daerah. Dengan demikian transfer dari pemerintah pusat yang besar akan menimbulkan disinsentif bagi pemerintah daerah dalam meningkatkan penerimaan daerah.

Lewis (2017) melakukan penelitian dampak pemekaran daerah di Indonesia terhadap pelayanan publik di Indonesia dengan menggunakan metode Difference in Difference (DiD) dan Generalized Method of Moment (GMM) sebagai alat analisisnya. Dampak yang diamati adalah akses pendidikan dan infrastruktur. Akses pendidikan yang diamati adalah rata-rata tingkat partisipasi murni SMP dan SMA sedangkan untuk akses infrastruktur adalah persentase rumah tangga di kabupaten yang memiliki akses terhadap air bersih dan sanitasi terlindungiData keempat variabel tersebut berasal dari SUSENAS (Survei Sosial Ekonomi Nasional) pada tahun 2001 hingga 2010. Variabel kontrol yang digunakan dalam analisis meliputi total belanja pemerintah daerah per kapita, ukuran populasi, persentase rumah tangga yang memiliki akses terhadap listrik, persentase penduduk miskin, koefisien Gini, pengeluaran rumah tangga per kapita. Hasil penelitiannya menyatakan bahwa Adanya pemekaran daerah tidak berdampak terhadap aspek pendidikan sedangkan dari aspek infrastruktur, daerah anak kondisinya lebih rendah dibandingkan dengan daerah induk. 
Penelitian lain juga dilakukan oleh Qibthiyyah (2010) yang melakukan penelitian tentang dampak pemekaran daerah di Indonesia terhadap outcome kesehatan dan pendidikan dengan menggunakan DiD sebagai alat analisisnya, Variabel outcome kesehatan yang dianalisis adalah angka kematian bayi, perhitungan angka kematian bayi berasal dari jumlah bayi yang meninggal berusia kurang dari satu tahun dibagi dengan jumlah kelahiran bayi yang hidup, dinyatakan dalam hal kematian per seribu kelahiran hidup. Selanjutnya untuk outcome pendidikan menggunakan tiga ukuran, yaitu rata-rata nilai ujian sekolah (menggunakan tahun ke tiga di tingkat SMP), tingkat kelulusan (berdasarkan lulusan SMP yang di wisuda dari perolehan nilai UNAS), dan tingkat drop out (berdasarkan status individu yang putus sekolah, bukan berdasarkan tahun ketika drop out terjadi). Alasan pemilihan pendidikan di tingkat SMP dikarenakan SMP termasuk dalam program wajib belajar sembilan tahun dan keberadaan sekolah di tingkat SMA tidak tersedia di semua daerah, terutama daerah yang baru mengalami pemekaran. Tahun yang diobservasi tergantung dari ketersediaan data, untuk tingkat kematian bayi menggunakan tahun 1993-2005 sedangkan rata-rata nilai ujian sekolah dan tingkat kelulusan menggunakan tahun 2001, 2003-2005. Hasil estimasi outcome kesehatan menunjukkan adanya peningkatan jumlah kematian bayi di daerah induk dibandingkan daerah anak. Sedangkan untuk outcome pendidikan, adanya penurunan pada tingkat drop out di daerah anak tidak berdampak pada peningkatan rata-rata nilai ujian sekolah.

\section{Metode Penelitian}

Untuk menganalisis dampak pemekaran daerah terhadap penelitian ini menggunakan metode Difference-in-Difference (DiD). Metode ini merupakan salah satu metode yang digunakan untuk mengevaluasi dampak dari suatu program. Metode ini mengukur variabel terdampak di daerah yang mengalami pemekaran dan daerah yang tidak mengalami pemekaran. Metode Difference-in-Difference digunakan untuk menganalisis adanya dampak dengan mensyaratkan berada dalam dua periode waktu, yaitu sebelum dan sesudah treatment. Dalam konteks penelitian ini, treatment adalah daerah yang mengalami pemekaran. Penelitian ini digolongkan sebagai penelitian kuasi- eksperimental karena meskipun peneliti dapat melakukan kontrol atas berbagai variabel yang berpengaruh, tetapi tidak cukup untuk melakukan eksperimen yang sesungguhnya.

Model Difference-in-Difference yang digunakan untuk mengestimasi dampak pemekaran daerah terhadap variabel terdampak di level kabupaten/kota pada tahun 2001 hingga 2014 adalah sebagai berikut:

$$
Y_{i t}=\alpha_{i}+\beta_{1}\left(T \times D_{i t}^{\text {umur mekar }}\right)+\beta_{2} X_{i t}+\varepsilon_{i t}
$$

dengan $\mathrm{Y}$ adalah variabel terdampak, dimana variabel terdampak yang dimati adalah variabel input belanja daerah, variabel output dan outcome pendidikan, serta output dan outcome ekonomi; T adalah Dummy daerah yang mengalami pemekaran (daerah yang mengalami pemekaran=1, daerah yang tidak mengalami pemekaran=0); $D^{\text {umur_mekar }}$ adalah variabel dummy periode pemekaran $(D=1$ ditahun setelah mekar, $D=0$ di tahun sebelum pemekaran; $X$ adalah variabel kontrol; $\alpha$ adalah fixed effect; $\beta_{1}$ adalah koefisien dari variabel interaksi (menunjukkan dampak dari pemekaran daerah); $\beta_{2}$ adalah Koefisien dari variabel kontrol; $\varepsilon$ adalah error term; i menyatakan Daerah (Cross Section); dan t adalah Time Series.

Setiap dari variabel terdampak memiliki variabel kontrol yang berbeda-beda tergantung dari komponen yang biasa mempengaruhi varibel terdampak tersebut dan sesuai dengan jurnal acuan pada penelitian sebelumnya. Variabel terdampak dari input belanja daerah terdiri atas variabel share belanja administrasi, share belanja modal, share belanja ekonomi, share belanja pendidikan, share belanja lingkungan, share belanja kesehatan, share belanja in- 
frastruktur, share belanja lainnya, share belanja pegawai, share belanja kegiatan keagamaan, dan share belanja sosial menggunakan lima variabel kontrol, yaitu total populasi di perkotaan, In GDP per kapita, In total populasi, share pendapatan asli daerah, dan share dana bagi hasil.

Selanjutnya variabel terdampak dari terkait output dan outcome pendidikan yang diteliti adalah variabel jumlah bangunan SD, jumlah bangunan SMP, dan jumlah bangunan SMA serta tingkat literasi semuanya menggunakan enam variabel kontrol yang sama, yaitu variabel total populasi di perkotaan, In area, In total populasi, In GDP harga konstan, In pendapatan asli daerah, dan yang terakhir In dana bagi hasil.

Lalu variabel terdampak dari output ekonomi adalah jasa publik berupa variabel akses listrik, akses sanitasi, akses air bersih Sedangkan yang terkait barang publik yang terdiri dari variabel panjang jalan yang rusak parah, panjang jalan yang memiliki penerangan, panjang jalan yang berkondisi baik, panjang jalan yang rusak ringan, persentase jalan desa yang beraspal, persentase jalan desa yang bertanah, persentase jalan desa yang diperkeras, serta persentase jalan desa yang lain.

Terakhir, variabel outcome ekonomi seperti variabel In total pengeluaran rumah tangga per kapita, In GDP per kapita, dan In GDP harga konstan menggunakan dua variabel kontrol yang sama, yaitu populasi penduduk di perkotaan dan In total pengeluaran per kapita. Selanjutnya variabel tingkat pengangguran dan In jumlah pekerja menggunakan tiga variabel kontrol yang sama yaitu variabel populasi penduduk di perkotaan, In total pengeluaran per kapita, dan In GDP harga konstan namun ada satu variabel kontrol yang berbeda dengan menambahkan variabel In Populasi terhadap variabel In jumlah pekerja. Sedangkan untuk variabel tingkat kemiskinan menggunakan tiga variabel kontrol, yaitu populasi penduduk di perkotaan, In dari total pengeluaran per kapita, dan In GDP per kapita.

Data

Data yang digunakan adalah data Indodapoer-World Bank tahun 2001 hingga tahun 2014. Data Indodapoer-World Bank merupakan gabungan data yang berasal dari berbagai sumber resmi di Indonesia baik data yang bersifat mikro maupun makro. Diantara keseluruhan daerah di Indonesia, yang diambil dalam penelitian hanya Daerah tingkat II, yaitu daerah kabupaten/kota yang mengalami pemekaran setelah adanya Peraturan Pemerintah Nomor 129 Tahun 2000 tentang Persyaratan pembentukan dan kriteria pemekaran, penghapusan, dan penggabungan daerah. Kriteria selanjutnya adalah daerah-daerah yang mengalami pemekaran diantara tahun 2000 hingga 2010.

Diantara 542 daerah otonom di Indonesia (tidak termasuk 1 kabupaten dan 5 kota di Provinsi DKI Jakarta) yang masuk di dalam penelitian sebanyak 491 daerah. Pada awal desentralisasi ada total 336 yang disebut sebagai daerah original. Daerah Original terdiri dari 238 daerah yang tidak pernah mengalami pemekaran dan 98 daerah yang mengalami pemekaran. 491 daerah yang masuk dalm penelitian terdiri dari 238 daerah yang tidak pernah mengalami pemekaran dan 253 daerah baru. Daerah baru terdiri dari daerah induk dan daerah anak. Daerah induk sebanyak 98 daerah dan 155 daerah anak. Daerah induk adalah daerah yang mengalami pemekaran dan daerah anak adalah daerah hasil dari pemekaran.

\section{Hasil dan Pembahasan}

\section{Gambaran Umum Pemekaran Daerah di Indonesia}

Pemekaran daerah di setiap provinsi, Secara keseluruhan hingga tahun 2018, Daerah Otonom di Indonesia sebanyak 542 Daerah. Rinciannya adalah 34 Provinsi, 415 Kabupaten (tidak termasuk 1 kabupaten di Provinsi DKI Jakarta), dan 93 Kota (tidak termasuk 5 kota di 
Provinsi DKI Jakarta). Perkembangan pemekaran daerah di setiap provinsi ditunjukkan pada Gambar 2 sebagai berikut:

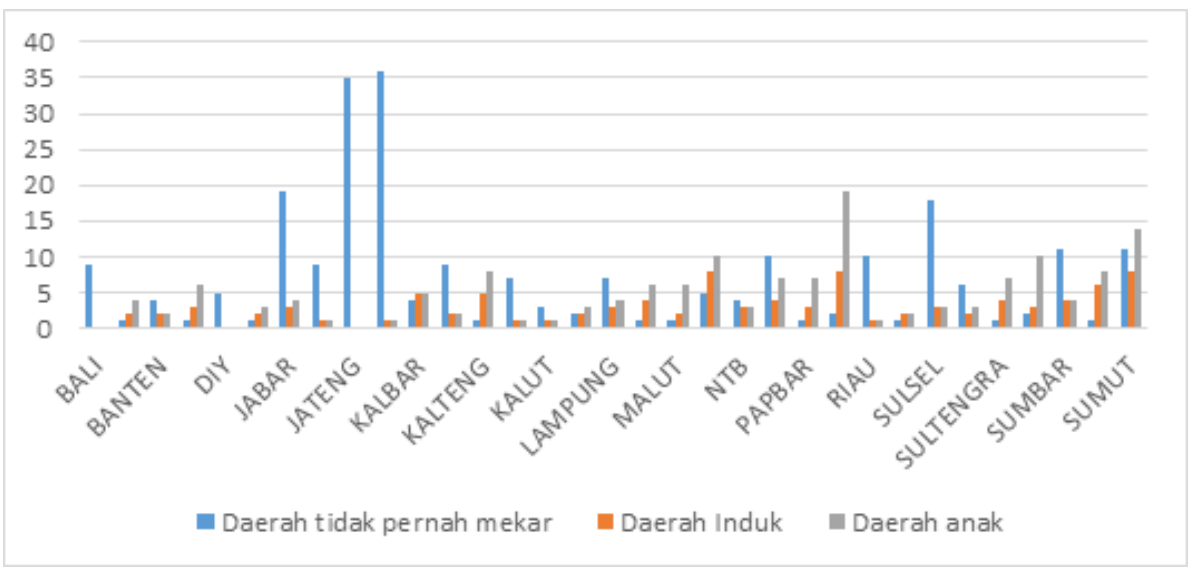

Sumber : Kementerian Dalam Negeri, 2018. Diolah.

\section{Gambar 2: Perkembangan Pemekaran Daerah di Setiap Provinsi, 2000 - 2010}

Gambar 2 diatas menunjukkan provinsi mana yang paling banyak mengalami pemekaran. Persebaran pemekaran secara keseluruhan paling banyak terjadi di Pulau Sumatera, Kalimantan, Sulawesi, Maluku, dan Papua. Jika ditinjau dari setiap provinsi, pemekaran daerah banyak terjadi di provinsi Papua, terdiri dari 8 daerah induk dan 19 daerah anak, Provinsi Sumatera Utara yang terdiri dari 8 daerah induk dan 14 daerah anak, dan terakhir Provinsi Nanggroe Aceh Darussalam yang terdiri dari 8 daerah induk dan 10 daerah anak.

Total daerah kabupaten/kota yang digunakan dalam penelitian adalah 491 daerah terdiri dari 238 daerah yang tidak pernah mengalami pemekaran, 98 daerah yang mengalami pemekaran atau disebut dengan daerah induk, dan 155 daerah anak. 491 Daerah tersebut diambil dari total keseluruhan 542 daerah yang berstatus sebagai Daerah Otonom. 51 daerah diantaranya tidak termasuk didalam penelitian dikarenakan 34 termasuk daerah tingkat I (daerah provinsi) dan 17 daerah tidak dimasukkan di dalam penelitian dikarenakan mengalami pemekaran diatas tahun 2010.

Variabel input belanja daerah pada penelitian ini dihitung berdasarkan besarnya persentase pos belanja dari total belanja keseluruhan. Karakteristik belanja daerah yang dianalisis dalam penelitian ini dimulai dari yang bernilai tertinggi adalah belanja administrasi, belanja lainnya, dan belanja pegawai.

Diikuti dengan besaran nilai belanja modal, pendidikan, infrastruktur, dan sosial dan terakhir ekonomi, kesehatan, dan kegiatan keagamaan mempunyai persentase yang paling kecil. Berikut adalah Statistik deskriptif belanja daerah ditunjukkan pada Tabel 1 sebagai berikut:

Tabel 1 : Statistik Deskriptif Variabel Input Belanja Daerah Tahun 2001 - 2014

\begin{tabular}{lccccc}
\hline \multicolumn{1}{c}{ Variabel Terdampak } & Observasi & Mean & Standar Deviasi & Min & Max \\
\hline Input Belanja Daerah & & & & & \\
\hline Share Belanja Administrasi & 3.620 & 32,17 & 14,53 & 1,07 & 100 \\
\hline Share Belanja Modal & 3.707 & 21,99 & 10,58 & 0 & 98,45 \\
\hline Share Belanja Ekonomi & 3.574 & 2,46 & 2,53 & 0,07 & 53,85 \\
\hline Share Belanja Pendidikan & 3.585 & 33,60 & 12,86 & 0,03 & 98,53 \\
\hline
\end{tabular}



Husna, D. \& Rumayya $\mid \begin{aligned} & \text { Analysis the Impact of Government Proliferantion } \\ & \text { on Educational and Economic }\end{aligned}$

\begin{tabular}{lccccc}
\hline \multicolumn{1}{c}{ Variabel Terdampak } & Observasi & Mean & Standar Deviasi & Min & Max \\
\hline Share Belanja Lingkungan & 3.379 & 1,74 & 2,57 & 0 & 86,70 \\
\hline Share Belanja Kesehatan & 3.580 & 8,48 & 3,52 & 0,59 & 44,41 \\
\hline Share Belanja Infrastruktur & 3.584 & 14,07 & 8,32 & 0,13 & 96,83 \\
\hline Share Belanja Lainnya & 3.682 & 8,39 & 5,32 & 0 & 100 \\
\hline Share Belanja Pegawai & 3.713 & 50,48 & 13,44 & 0,09 & 100 \\
\hline Share Belanja Kegiatan Keagamaan & 712 & 0,59 & 0,74 & 0 & 9,11 \\
\hline Share Belanja Sosial & 3.230 & 1,10 & 5,35 & 0 & 98,96 \\
\hline
\end{tabular}

Sumber : World Bank, diolah

Outcome yang diamati dalam penelitian ini adalah Tingkat Literasi yang dicapai oleh daerah yang mengalami pemekaran. Indikatornya dilihat dari capaian berapa banyak bangunan sekolah yang sudah terbangun, yaitu terkait bangunan sekolah SD, bangunan Sekolah SMP, dan bangunan Sekolah SMA.

Bangunan sekolah SD dalam suatu daerah ada minimal 2 bangunan dan maksimum ada sejumlah 2696 bangunan. Untuk bangunan sekolah SMP, ada minimal 3 bangunan sedangkan maksimum ada 735 bangunan. Dan bangunan sekolah SMA dalam suatu daerah ada minimal 1 bangunan dan maksimal ada 439. Dalam jabaran diatas telah menginformasikan bahwa semakin tinggi jenjang pendidikan maka jumlah bangunan sekolah semakin mengerucut makin kecil sehingga hal ini mengidentifikasi makin ada banyak anak yang semakin tersisihkan dan tidak bias mencapai pendidikan yang tinggi.

Untuk Capaian / Outcome yang diamati dalam penelitian ini hal yang diamati adalah Tingkat Literasi dalam suatu daerah, minimum bernilai 13,75 persen dan maksimum bernilai 100 persen. Secara keseluruhan, Statistik Deskriptif dari variabel output dan outcome pendidikan ditunjukkan pada Tabel 2 sebagai berikut:

Tabel 2 : Statistik Deskriptif Variabel Output dan Outcome Pendidikan Tahun 2001 - 2014

\begin{tabular}{lccccc}
\hline \multicolumn{1}{c}{ Variabel Terdampak } & Observasi & Mean & Standar Deviasi & Min & Max \\
\hline Variabel Output Pendidikan & & & & & \\
\hline Jumlah Bangunan SD & 1.343 & 453,08 & 357,81 & 2 & 2696 \\
\hline Jumlah Bangunan SMP & 1.341 & 100,19 & 85,48 & 3 & 735 \\
\hline Jumlah Bangunan SMA & 1.316 & 51,59 & 49,11 & 1 & 439 \\
\hline Variabel Outcome Pendidikan & & & & & 13,75 \\
\hline Tingkat Literasi & 4.637 & 90,78 & 9,91 & & 100 \\
\hline
\end{tabular}

Sumber : World Bank, diolah

Karakteristik Output dan Outcome dari Aspek Ekonomi yang mana Output Ekonomi terdiri dari Barang dan Jasa Publik. Barang Publik yang dimaksud terdiri dari Panjang Jalan yang Rusak, Panjang Jalan yang memiliki penerangan, Panjang Jalan yang Bagus, Panjang Jalan yang Mulus, Persentase Jalan Desa yang beraspal, Persentase Jalan Desa yang Berlumpur, Persentase Jalan Desa yang Berbatu, serta Persentase Jalan Desa yang lain. Sedangkan Jasa Publik terdiri dari Akses Listrik, Akses Sanitasi, dan Akses Air Bersih.Dari Output tersebut berdampak terhadap Outcome Ekonomi dalam 3 Aspek, yaitu terkait Aspek Pendapatan per Kapita dilihat dari In total pengeluaran per Kapita, In GDP per Kapita, serta In GDP harga konstan, Aspek Tenaga Kerja dilihat dari Tingkat Pengangguran dan Jumlah Pekerjanya, serta yang terakhir melihat dampaknya terhadap aspek Kemiskinannya melalui Tingkat Kemiskinannya. 
Untuk Barang Publik, Panjang Jalan yang Rusak di setiap daerah minimal memiliki panjang $1 \mathrm{Km}$ dan maksimal memiliki panjang $2309 \mathrm{Km}$. Panjang Jalan yang memiliki fasilitas penerangan memiliki panjang minimal $4 \mathrm{Km}$, serta maksimal memiliki panjang $1439 \mathrm{Km}$. Panjang Jalan yang Bagus memiliki panjang minimal $1 \mathrm{Km}$ dan maksimal memiliki panjang $1655 \mathrm{Km}$. Sedangkan Panjang Jalan yang Mulus memiliki panjang minimal $1 \mathrm{Km}$, serta panjang maksimal $1559 \mathrm{Km}$.Persentase Jalan Desa yang Beraspal dalam suatu daerah minimal sebesar 1,39 persen dan maksimal sebesar 100 persen, Persentase Jalan Desa yang Berlumpur memiliki luasan 0,23 persen dan maksimal 95,62 persen, Persentase Jalan Desa yang Berbatuan memiliki luasan minimal 0,52 persen dan maksimal 73,21 persen. Sedangkan persentase Jalan desa yang lainnya memiliki luasan minimal 0,06 persen dan maksimal 18,71 persen.

Variabel output berpengaruh terhadap variable outcome dalam 3 hal, yaitu pendapatan per kapita minimal bernilai 11,19 persen dan bernilai maksium sebesar 15,17 persen, GDP per Kapita minimal bernilai 0,19 persen dan maksimal bernilai 5,60 persen, serta GDP harga konstan minimal sebesar 11,58 persen dan maksimal sebesar 18,50 persen. Dalam aspek Tenaga Kerja, Tingkat pengangguran dalam suatu daerah minimal sebesar 0,11 persen dan maksimal sebesar 22,14 persen. Selanjutnya Jumlah Pekerja dalam suatu daerah minimal sebesar 9,33 persen dan maksimal sebesar 14,62 persen. Terakhir dalam aspek kemiskinan diukur dengan Tingkat Kemiskinan yang minimal sebesar 1,41 persen dan maksimal sebesar 60,89 persen. Secara keseluruhan, Statistik Deskriptif dari variabel output dan outcome ekonomi ditunjukkan pada Tabel 3 sebagai berikut:

Tabel 3: Statistik Deskriptif Variabel Output dan Outcome Ekonomi Tahun 2001 - 2014

\begin{tabular}{|c|c|c|c|c|c|}
\hline Variabel Terdampak & Observasi & Mean & Standar Deviasi & Min & Max \\
\hline \multicolumn{6}{|l|}{ Variabel Output Ekonomi } \\
\hline \multicolumn{6}{|l|}{$\underline{\text { Jasa Publik }}$} \\
\hline Akses Listrik & 3.984 & 85,71 & 18,92 & 0,55 & 100 \\
\hline Akses Sanitasi & 4.318 & 61,11 & 17,42 & 4,165 & 96,75 \\
\hline Akses Air Bersih & 4.317 & 51,43 & 20,43 & 0,15 & 100 \\
\hline \multicolumn{6}{|l|}{ Barang Publik } \\
\hline Panjang Jalan yang Rusak Parah & 498 & 203,92 & 267,49 & 1 & 2309 \\
\hline $\begin{array}{l}\text { Panjang Jalan yang memiliki Pen- } \\
\text { erangan }\end{array}$ & 554 & 256,48 & 178,06 & 4 & 1439 \\
\hline Panjang Jalan yang Berkondisi Baik & 590 & 195,20 & 170,73 & 1 & 1655 \\
\hline Panjang Jalan yang Rusak Ringan & 589 & 275,23 & 214,64 & 1 & 1559 \\
\hline Persentase Jalan Desa yang Beraspal & 1.340 & 66,29 & 26,41 & 1,39 & 100 \\
\hline $\begin{array}{l}\text { Persentase Jalan Desa yang Ber- } \\
\text { tanah }\end{array}$ & 1.033 & 14,70 & 15,94 & 0,23 & 95,62 \\
\hline $\begin{array}{l}\text { Persentase Jalan Desa yang Diper- } \\
\text { keras }\end{array}$ & 1.175 & 21,55 & 15,32 & 0,52 & 73,21 \\
\hline Persentase Jalan Desa yang Lainnya & 375 & 1,56 & 2,09 & 0,06 & 18,71 \\
\hline \multicolumn{6}{|l|}{ Variabel Outcome Ekonomi } \\
\hline \multicolumn{6}{|l|}{ Pendapatan per Kapita } \\
\hline In Total Pengeluaran per Kapita & 4.298 & 12,86 & 0,76 & 11,19 & 15,17 \\
\hline In GDP per Kapita & 4.366 & 1,71 & 0,68 & 0,19 & 5,60 \\
\hline In GDP harga konstan & 4.368 & 14,72 & 1,06 & 11,58 & 18,50 \\
\hline \multicolumn{6}{|l|}{ Tenaga Keria } \\
\hline Tingkat Pengangguran & 2.345 & 6,71 & 3,56 & 0,11 & 22,14 \\
\hline
\end{tabular}




\begin{tabular}{lccccc}
\hline Variabel Terdampak & Observasi & Mean & Standar Deviasi & Min & Max \\
\hline In Jumlah Pekerja & 2.345 & 12,26 & 0,88 & 9,33 & 14,62 \\
\hline Kemiskinan & & & & & \\
\hline Tingkat Kemiskinan & 4.361 & 15,75 & 8,97 & 1,41 & 60,89 \\
\hline
\end{tabular}

Sumber : World Bank, Diolah

Hasil estimasi dengan metode Difference in Difference (DiD) pada penelitian ini baik pada daerah yang mengalami pemekaran atau daerah yang tidak mengalami pemekaran, perlakuannya terhadap variabel kontrol adalah sama tergantung dari jenis variabel terdampak yang diamati. Setelah itu dapat dilihat tingkat signifikansinya. Ringkasan hasil estimasi variabel yang signifikan dengan nilai koefisien interaksi dan standard error ditampilkan pada Tabel 4 berikut:

Tabel 4 : Hasil Estimasi Variabel Terdampak yang Signifikan

\begin{tabular}{|c|c|c|}
\hline Jenis Variabel & Coef. Interaksi & Robust Std.Err. \\
\hline \multicolumn{3}{|l|}{ Variabel Input Belanja Daerah } \\
\hline Share Belanja Administrasi & $5,583 * * *$ & 1,324 \\
\hline Share Belanja Modal & $6,782 * * *$ & 0,794 \\
\hline Share Belanja Infrastruktur & $4,010 * * *$ & 0,696 \\
\hline Share Belanja Pendidikan & $-6,900 * * *$ & 1,031 \\
\hline Share Belanja Pegawai & $-7,756 * * *$ & 0,893 \\
\hline Share Belanja Keagamaan & $-0,505^{* *}$ & 0,222 \\
\hline \multicolumn{3}{|l|}{ Variabel Output Pendidikan } \\
\hline Jumlah Bangunan SMP & $9,285 * *$ & 4,040 \\
\hline Jumlah Bangunan SMA & $6,626^{*}$ & 3,739 \\
\hline \multicolumn{3}{|l|}{ Variabel Outcome Pendidikan } \\
\hline Tingkat Literasi & $-3,003 * *$ & 1,365 \\
\hline \multicolumn{3}{|l|}{ Variabel Output Ekonomi } \\
\hline \multicolumn{3}{|l|}{$\underline{\text { Jasa Publik }}$} \\
\hline Akses Listrik & $2,049 * *$ & 0,914 \\
\hline Akses Air Bersih & $-2,117 * * *$ & 0,783 \\
\hline \multicolumn{3}{|l|}{ Barang Publik } \\
\hline Persentase Jalan Desa yang Beraspal & $-5,262 * * *$ & 1,624 \\
\hline Persentase Jalan Desa yang Bertanah & $3,877^{* * *}$ & 1,315 \\
\hline Persentase Jalan Desa yang Diperkeras & $3,978 * * *$ & 1,271 \\
\hline \multicolumn{3}{|l|}{ Variabel Outcome Ekonomi } \\
\hline \multicolumn{3}{|l|}{ Pendapatan per Kapita } \\
\hline In Total Pengeluaran per Kapita & $0,644 * * *$ & 0,041 \\
\hline In GDP per Kapita & $-0,082 * * *$ & 0,028 \\
\hline \multicolumn{3}{|l|}{ Tenaga Kerja } \\
\hline In Jumlah Pekerja & $0,025^{*}$ & 0,013 \\
\hline \multicolumn{3}{|l|}{ Kemiskinan } \\
\hline Tingkat Kemiskinan & $-1,289 * * *$ & 0,457 \\
\hline
\end{tabular}

Keterangan : ***Signifikan 1\%, **Signifikan 5\%, *Signifikan $10 \%$

Sumber : World Bank, Diolah 
Tabel 4 menunjukkan hasil estimasi dari koefisien dampak. Sebelum melihat dampak pemekaran daerah terhadap outcome, maka hal yang perlu diperhatikan terlebih dahulu adalah terkait komponen input belanja daerah yang mengalami pemekaran akan lebih memfokuskan belanjanya untuk apa saja. Dari hasil estimasi diketahui bahwa daerah yang mengalami pemekaran lebih signifikan meningkatkan belanja administrasi sebesar 5,583 persen, signifikan meningkatkan belanja modal sebesar 6,782 persen, serta signifikan meningkatkan belanja infrastruktur sebesar 4,010 persen. Selanjutnya daerah yang mengalami pemekaran juga mengurangi alokasi belanjanya terhadap beberapa hal. Berdasarkan hasil estimasi, daerah yang mengalami pemekaran signifikan mengurangi alokasi belanja pendidikan sebesar 6,9 persen, signifikan mengurangi belanja pegawai sebesar 7,75 persen, serta signifikan mengurangi belanja keagamaan sebesar 0,505 persen.

Dari hasil estimasi terkait keuangan daerah yang mengalami pemekaran, salah satu aspek yang akan dilihat adalah kemanakah pengalokasian belanja infrastruktur tersebut digunakan, oleh karena itu peneliti mencoba melihat dampaknya terhadap outcome pendidikan dan outcome ekonomi. Untuk melihat dampaknya terhadap outcome pendidikan, maka yang dilihat terlebih dahulu adalah output pendidikannya, hasil estimasi menunjukkan signifikan meningkatkan jumlah sekolah SMP sebanyak 9 sekolah dan signifikan meningkatkan jumlah sekolah SMA sebanyak 6 sekolah. Selanjutnya dilihat dampaknya terhadap outcome adalah signifikan berpengaruh buruk menurunkan tingkat literasi sebesar 3 persen.

Selanjutnya terkait output ekonomi yang diamati dalam penelitian ini melihat dari sisi barang dan jasa publik. Hasil estimasi pada barang publik menunjukkan adanya buruk dari pemekaran daerah, yaitu meningkatkan jalanan desa yang bertanah dan diperkeras sebesar 3,87 persen dan 3,97 persen serta signifikan menurunkan jalanan desa yang beraspal sebesar 5,2 persen. Sementara itu, hasil estimasi pada jasa publik menunjukkan adanya pengaruh signifikan dari pemekaran daerah dalam meningkatkan akses listrik sebesar 2,04 persen, dan menurunkan akses terhadap air bersih sebesar 2,17 persen.

Selanjutnya melihat dampaknya terhadap outcome ekonomi, untuk pendapatan per kapitanya diproksi melalui total pengeluaran rumah tangga per kapita dan In GDP per kapita. Hasil estimasi menunjukkan bahwa pemekaran daerah signifikan meningkatkan total pengeluaran rumah tangga per kapita sebesar 64 persen. Namun, disisi lain pemekaran daerah signifikan menurunkan GDP per kapita sebesar 8,2 persen. Dari sisi tenaga kerja, pemekaran daerah signifikan dalam meningkatkan jumlah pekerja sebesar 2,5 persen. Sementara itu dari sisi kemiskinan, pemekaran daerah berpengaruh signifikan dalam menurun tingkat kemiskinan sebesar 1,28 persen.

Input belanja daerah tidak semua pos belanja mengalami peningkatan. Daerah yang mengalami pemekaran cenderung mengalokasikan untuk belanja administrasi, belanja modal, dan belanja infrastruktur hal ini sejalan dengan penelitian dari Sjahrir (2013) yang menyatakan daerah yang mengalami pemekaran cenderung mengalokasikan anggaran belanjanya untuk belanja administrasi karena hampir sepertiga dari total anggaran, belanja administrasi adalah yang terbesar kedua dalam pos anggaran dan merupakan merupakan indikator besarnya mis alokasi yang besar terhadap sumber daya publik. Belanja administrasi yang tinggi sebagai indikasi dari tata kelola pemerintahan yang buruk yang berdampak pada kurangnya akuntabilitas di tingkat lokal. Selanjutnya daerah yang mengalami pemekaran juga cenderung mengurangi pengalokasian untuk belanja pendidikan, belanja pegawai, dan belanja kegiatan keagamaan hal ini juga sejalan dengan penelitian dari Sjahrir (2013) yang menyatakan pada awal tahun pemekaran daerah, memang ada penurunsan dalam belanja pegawai dikarenakan masih menggunakan bantuan dari pegawai negeri sipil daerah induk, namun pada tahun ke empat dan kelima akan ada peningkatan pada belanja pegawai. 
Dari pengalokasian belanja APBD tersebut, peneliti mencoba melihat dan menganalisis dampak dari adanya pemekaran daerah terhadap output dan outcome pendidikan. Secara umum, dampak dari daerah yang mengalami pemekaran terhadap outcome pendidikan (tingkat literasi) adalah berdampak buruk. Hal ini dibuktikan dengan adanya penurunan tingkat literasi pada daerah-daerah yang mengalami pemekaran, seperti yang ditunjukkan pada hasil estimasi Tabel 4 Tingkat literasi cenderung dengan pengukuran kemampuan membaca dan menulis di usia Sekolah Dasar (SD). Sementara itu, hasil dari penelitian ini menunjukkan bahwa pemekaran daerah tidak terbukti mempengaruhi jumlah SD. Bahkan, hasil menunjukkan adanya indikasi bahwa pemekaran daerah cenderung mengurangi jumlah SD. Selain itu, dampak buruk pemekaran daerah terhadap outcome pendidikan juga mungkin terjadi karena pemekaran menurunkan alokasi pengeluaran pendidikan dalam APBD daerah-daerah yang mengalami pemekaran. Hasil ini sejalan dengan hasil pada penelitian yang dilakukan oleh Qibthiyyah (2010) yang menunjukkan bahwa dampak daerah yang mengalami pemekaran terhadap outcome pendidikan secara keseluruhan tidak berpengaruh terhadap perbaikan rata-rata nilai ujian sekolah meskipun ada penurunan jumlah drop out.

Selanjutnya, peneliti mencoba untuk melihat dan menganalisis dampak dari adanya pemekaran daerah terhadap output dan outcome ekonomi, yang dilihat dari komponen pendapatan per kapita, jumlah pekerja, dan tingkat kemiskinan. Pada penelitian ini, pendapatan per kapita di proksi dengan menggunakan total pengeluaran rumah tangga per kapita dan GDP per kapita. Hasil estimasi pada Tabel 4 menunjukkan bahwa pemekaran daerah berdampak pada peningkatan total pengeluaran rumah tangga per kapita. Hasil ini konsisten dengan dampak pemekaran daerah terhadap tingkat kemiskinan, yang menunjukkan bahwa adanya pemekaran daerah berdampak pada penurunan tingkat kemiskinan.

Namun, disisi lain pemekaran daerah justru berdampak pada penurunan GDP per kapita. Hasil ini bertolak belakang dengan hasil sebelumnya yang menunjukkan bahwa pemekaran daerah meningkatkan total pengeluaran rumah tangga per kapita. Salah satu indikasi yang menyebabkan hal tersebut adalah adanya perbedaan pertumbuhan antara komponen-komponen pembentuk GDP. Pada dasarnya, GDP terbentuk dari 4 komponen, yaitu rumah tangga (konsumsi/c), perusahaan (investasi/i), pemerintah (g) dan luar negeri (net ekspor). Dalam hal ini, perbedaan dampak pemekaran daerah mungkin terjadi karena komponen rumah tangga (terkait dengan kegiatan konsumsi) mengalami peningkatan, sementara tiga komponen lain, khususnya komponen pengeluaran sektor swasta/perusahaan justru mengalami penurunan akibat adanya penurunan iklim investasi. Pada akhirnya, dampak total dari seluruh komponen terhadap GDP menjadi negatif. Hasil ini didukung oleh penelitian yang dilakukan oleh Bappenas (2008); Jaweng (2014); Kemendagri (2014) yang menyatakan daerah yang mengalami pemekaran mempunyai kapasitas dan komitmen yang minim, terlihat dari lemahnya investasi publik, belum kondusifnya iklim berusaha, kurangnya kapasitas daya serap anggaran, dan juga kecilnya alokasi anggaran untuk pembangunan.

\section{Kesimpulan}

Berdasarkan latar belakang, rumusan masalah, dan pembahasan, maka simpulan dalam penelitian ini. Pertama, dampak pemekaran daerah terhadap kondisi pendidikan secara umum adalah signifikan menurunkan tingkat literasi di daerah yang mengalami pemekaran. Hal ini mungkin terjadi karena pemekaran daerah tidak terbukti secara signifikan mempengaruhi jumlah bangunan SD, bahkan ada indikasi mengurangi. Indikasi lainnya dari segi input adalah penurunan yang signifikan pada alokasi belanja pendidikan dalam APBD daerah-daerah yang mengalami pemekaran. 
Kedua, dampak pemekaran daerah terhadap kondisi ekonomi secara umum adalah signifikan meningkatkan pendapatan per kapita, jumlah pekerja, dan signifikan menurunkan tingkat kemiskinan. Ini artinya pemerintah daerah yang mengalami pemekaran telah berhasil mentransfer dana ke masyarakat namun daerah yang mengalami pemekaran juga ada indikasi pemburukan dalam iklim investasi sehingga menurunkan pengeluaran dari sektor swasta yang mana secara keseluruhan berpengaruh menurunkan GDP harga konstan.

Berdasarkan simpulan yang telah dipaparkan, terdapat beberapa saran yang dapat diberikan. Pertama, Pemerintah disarankan memiliki grand desain berupa prasyarat yang lebih ketat mengenai kebijakan pemekaran untuk memastikan agar daerah-daerah yang mengalami pemekaran benar-benar daerah yang mampu meningkatkan kesejahteraan masyarakat pasca pemekaran. Kedua, perlu adanya upaya yang lebih serius terhadap monitoring, evaluasi, dan asistensi dari pemerintah pusat terhadap daerah-daerah yang telah mengalami pemekaran terutama di sector pendidikan dan ekonomi (khususnya dalam iklim usaha dan investasi). Dan Ketiga, saran bagi peneliti selanjutnya adalah menganalisis dampak pemekaran dengan menggunakan lebih banyak indicator variable outcome dari sektor lainnya seperti kesehatan.

\section{Daftar Pustaka}

Badan Perencanaan Pembangunan Nasional. (2008). Studi Evaluasi Dampak Pemekaran Daerah Tahun 2001 - 2007. Jakarta : BRIDGE.

Hayek, F. A. (1945). The use of knowledge in society. The American economic review, 35(4), 519-530.

Jaweng, R. E. (2014). Pemekaran dan Daerah Otonom Baru : Bayi Prematur yang Tumbuh Norma. Analisis CSIS, Vol. 43

Kementrian Dalam Negeri. (2014). Pembentukan Daerah-Daerah Otonom di Indonesia Sampai Dengan Tahun 2014.

Lewis, B. D. (2017). Does local government proliferation improve public service delivery? Evidence from Indonesia. Journal of Urban Affairs, 39(8), 1047-1065. https://doi.org/10 .1080/07352166.2017.1323544

Musgrave, R. A. (1959). The Theory of Public Finance. New York : McGraw Hill.

Oates, W. E. (1972). Fiscal Federlism (N. Y. H. B. Jovanovich (ed.)).

Qibthiyyah, R. (2010). The Impact of Indonesian Local Government Proliferation on Health and Education Outcomes (Draft) Riatu M. Qibthiyyah.

Sjahrir, B. S., Kis-Katos, K., \& Schulze, G. G. (2013). Political budget cycles in Indonesia at the district level. Economics Letters. 120(2), 34.

World Bank. (2012). Indonesia subnational public expenditure review: Optimizing subnational performance for better services and faster growth. Jakarta, Indonesia : World Bank.

Zaenuddin, M. (2015). Isu, Problematika, dan Dinamika Perekonomian, dan Kebijakan Publik. Yogyakarta : Deepublish. 